\title{
Starzenie się personelu medycznego - wyzwanie dla polskiego systemu ochrony zdrowia
}

\author{
Zofia Skrzypczak*
}

Celem pracy jest przedstawienie zjawiska starzenia się personelu medycznego (lekarze, pielegniarki i położna) na tle starzejącego się społeczeństwa Polski. Rosnacy udziat w strukturze profesjonalistów medycznych majacych prawo wykonywania zawodu grup wiekowych: „55-64 lata” oraz „65 lat i więcej”, przy relatywnie niewielkim i malejacym udziale ludzi młodych grozi wystapieniem braku tzw. zastępowalności pokoleniowej. Dzieje się to przy równocześnie występującym zjawisku starzenia się spoteczeństwa, rodzacym zwiększone zapotrzebowanie na ustugi stricte medyczne i opiekuńcze, konieczność rozbudowy systemu opieki dtugoterminowej, rehabilitacji itp. Zwrócono uwagę na obecne problemy oraz te, które moga pojawić się i pogtębić $w$ niedalekiej już przyszłości.

Słowa kluczowe: zasoby ludzkie w ochronie zdrowia, starzenie się personelu medycznego, lekarze, pielęgniarki, położne.

Nadesłany: 11.09.18 | Zaakceptowany do druku: 18.12.18

\section{Aging of medical personnel - a challenge for the Polish healthcare system}

The aim of this paper is presentation of the medical personnel (doctors, nurses and midwife) aging phenomenon against the background of the aging Polish society. The growing share in the structure of medical professionals with the license in the age group: "55-64 years" and "65 years and more", with a relatively small and decreasing participation of young people, threatens the occurrence of the lack of the so-called generational replacement. This is happening with the simultaneous occurrence of the phenomenon of an aging population that raises the increased demand for strictly medical and care services, the need to develop a long-term care system, rehabilitation, etc. Attention was paid to the current problems and those that may arise and deepen in the near future.

Keywords: human resources in health care, aging of medical personel, doctors, midwifes, nurses.

Submitted: 11.09.18 | Accepted: 18.12.18

JEL: I15, J11, J14

\footnotetext{
Zofia Skrzypczak - dr, Uniwersytet Warszawski, Wydział Zarządzania.

Adres do korespondencji: Uniwersytet Warszawski, Wydział Zarządzania, ul. Szturmowa 1/3, 02-678 Warszawa; e-mail: Skrzypczak@wz.uw.edu.pl.
} 


\section{Wprowadzenie}

Istotną cechą charakterystyczną współczesnych społeczeństw jest przyspieszony proces ich starzenia się. Zmiany w strukturze populacji, będące efektem starzenia się społeczeństw, mają istotny wpływ na zasoby siły roboczej - ich wielkość i strukturę, na stan budżetu państwa, konkurencyjność gospodarek. (Suchecka i Jewczak, 2018). Starzenie się społeczeństw oznacza równocześnie starzenie się grup wykonujących różne zawody i pełniących rozmaite funkcje społeczno-ekonomiczne.

Zasoby ludzkie są jednym z zasadniczych elementów systemu opieki zdrowotnej w każdym kraju. Ich liczebność i struktura determinują w dużym stopniu jakość świadczonych usług medycznych, dostępność opieki medycznej, wpływają na opinie pacjentów o funkcjonowaniu systemu opieki zdrowotnej. Zasoby ludzkie rozumiane sa także jako zasoby kwalifikacji i umiejętności wszystkich pracowników, funkcjonujących w systemie opieki zdrowotnej (Wyzwania, 2009).

W starzejącym się społeczeństwie, wymagającym coraz szerszego wachlarza oraz większej ilości i częstotliwości świadczonych usług medycznych, starzeje się również personel medyczny (występujący w niezadowalającej ilości).

Celem niniejszego opracowania jest analiza zjawiska starzenia się personelu medycznego w Polsce oraz problemów, które to zjawisko generuje obecnie i będzie generować w przyszłości, zwłaszcza w obliczu starzejącego się polskiego społeczeństwa. Rozważania dotyczą głównych i naj- bardziej licznych grup profesjonalistów medycznych - lekarzy oraz pielęgniarek i położnych.

W pracy posłużono się analizą opisową, wykorzystano dane statystyki publicznej i materiały źródłowe.

\section{Zasoby ludzkie w polskim systemie ochrony zdrowia i ich wykorzystanie}

Zawodem medycznym jest zajęcie polegające na działaniach medycznych oraz udzielaniu świadczeń zdrowotnych w celu ochrony zdrowia pacjenta. Istnieją uregulowania prawne, dzięki którym można wyróżnić zawody medyczne, takie jak: lekarz i lekarz dentysta, pielęgniarka i położna, diagnosta laboratoryjny, ratownik medyczny i farmaceuta. Zawody medyczne są tzw. zawodami regulowanymi. Posiadanie prawa wykonywania zawodu medycznego, np. lekarza, pielęgniarki i położnej, uzyskuje się z chwila wpisania osoby zainteresowanej do stosownego rejestru prowadzonego przez Naczelną Izbę Lekarską oraz Izbę Pielęgniarek i Położnych. W większości krajów europejskich dane statystyczne dotyczące zasobów ludzkich w ochronie zdrowia zawierają informacje zarówno o liczbie osób uprawnionych do wykonywania określonych zawodów medycznych, jak też o liczbie osób faktycznie pracujących w sektorze ochrony zdrowia.

W tabeli 1 przedstawiono zestawienie liczby lekarzy, pielęgniarek i położnych mających prawo wykonywania zawodu oraz zatrudnionych w systemie ochrony zdrowia w Polsce w latach 2010-2016.

Tabela 1. Liczba lekarzy, pielęgniarek i położnych mających prawo wykonywania zawodu oraz zatrudnionych w placówkach sektora ochrony zdrowia w Polsce w latach 2010-2016

\begin{tabular}{|c|c|c|c|c|c|c|}
\hline \multirow{2}{*}{ Rok } & \multicolumn{3}{|c|}{ Z prawem wykonywania zawodu } & \multicolumn{3}{c|}{ Zatrudnieni w ochronie zdrowia } \\
\cline { 2 - 7 } & lekarze & pielęgniarki & Położne & lekarze & pielęgniarki & położne \\
\hline 2010 & 134292 & 282420 & 34302 & 79337 & 184944 & 22193 \\
\hline 2011 & 136208 & 282483 & 34607 & 82376 & 194225 & 22730 \\
\hline 2012 & 137109 & 285339 & 35154 & 82944 & 200138 & 24069 \\
\hline 2013 & 139595 & 279979 & 34826 & 83371 & 189014 & 22473 \\
\hline 2014 & 141390 & 282472 & 35468 & 85789 & 187597 & 21949 \\
\hline 2015 & 142962 & 285431 & 36103 & 86533 & 185860 & 22051 \\
\hline 2016 & 144982 & 288446 & 36839 & 89819 & 184400 & 22400 \\
\hline
\end{tabular}

Źródło: zestawienie własne na podstawie Biuletynów Statystycznych Ministerstwa Zdrowia z lat 2011-2017, Centrum Systemów Informacyjnych Ochrony Zdrowia, Warszawa, www.csioz.gov.pl 
Liczba lekarzy mających prawo wykonywania zawodu wzrosła w latach 2010-2016 ze 135 tys. do 145 tys. (wzrost o 8\%), natomiast zatrudnienie $\mathrm{w}$ systemie ochrony zdrowia wzrosło z 80 tys. do prawie 90 tys. (wzrost o 12,5\% i stała tendencja wzrostowa).

Dominującą liczebnie grupą wśród profesjonalistów medycznych są w Polsce pielęgniarki - w latach 2010-2016 liczba pielęgniarek legitymujących się prawem wykonywania zawodu minimalnie wzrosła: z 282,5 tys. do 288,5 tys. (wzrost o nieco ponad $2 \%$ ), a ich zatrudnienie w sektorze publicznym i niepublicznym wahało się w przedziale. 185-200 tys. pielęgniarek (z tendencją spadkową w ostatnim okresie). Liczba położnych mających prawo wykonywania zawodu wzrosła w latach 2010-2016 z nieco ponad 34 tys. do ponad 36,5 tys. (wzrost o prawie 7,5\%); natomiast zatrudnienie położnych w sektorze ochrony zdrowia wahało się w analizowanym okresie w przedziale 22-24 tys. osób.

Niezwykle istotne jest ustalenie relacji między profesjonalistami zatrudnionymi w placówkach sektora ochrony zdrowia a zasobami lekarzy, pielęgniarek i położnych, mających prawo wykonywania zawodu (rysunek 1).

Rysunek 1. Lekarze, pielęgniarki i położne zatrudnione w systemie ochrony zdrowia w Polsce w latach 2010-2016 jako \% mających prawo wykonywania zawodu

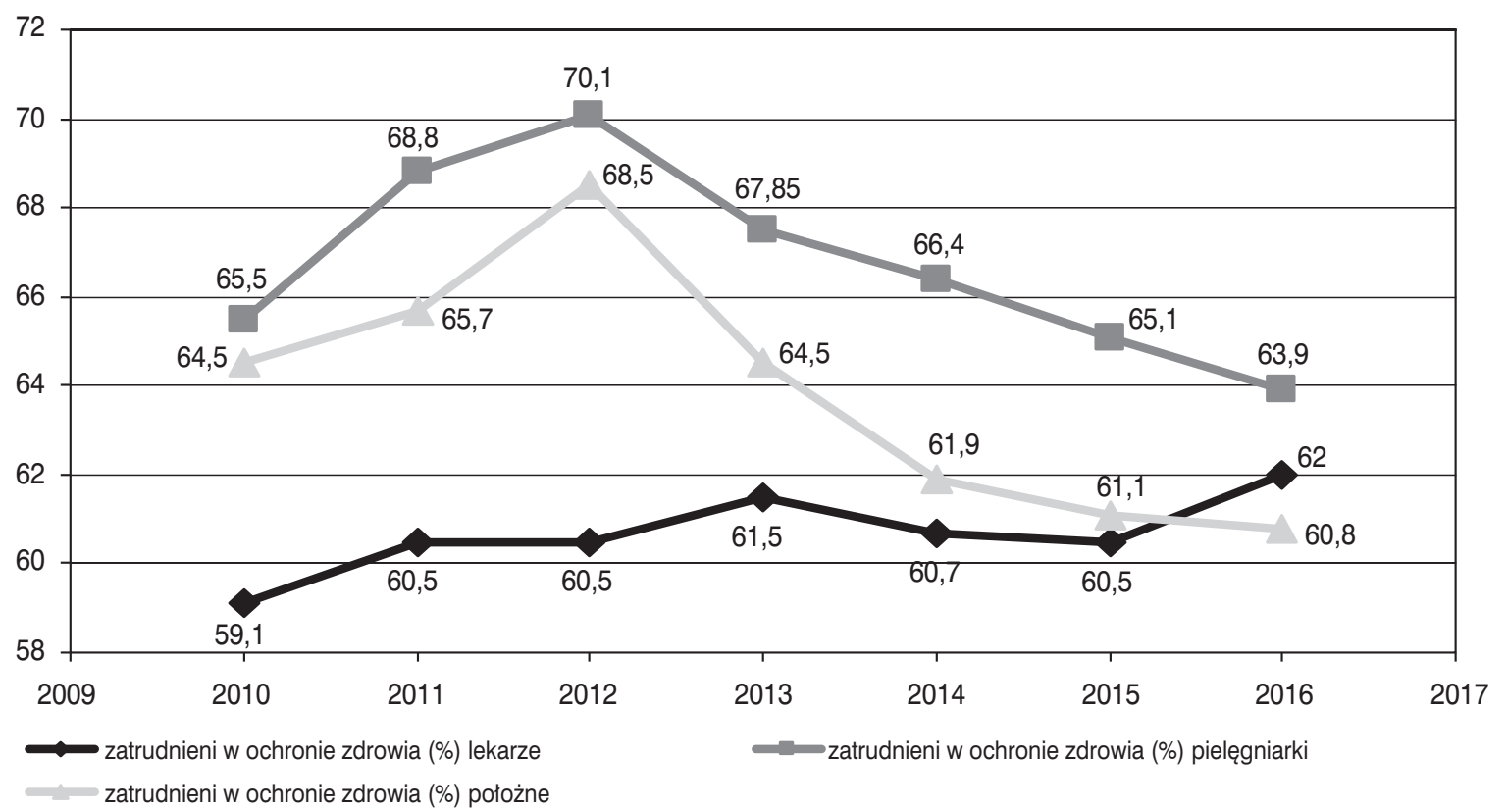

Źródło: obliczenie własne na podstawie tabeli 1.

Spośród objętych analizą zawodów medycznych jedynie $\mathrm{w}$ przypadku lekarzy odnotowano w latach 2010-2016 niewielką tendencję wzrostową odsetka posiadających prawo wykonywania zawodu i zatrudnionych $\mathrm{w}$ systemie opieki zdrowotnej (z poziomu $59 \%$ do $62 \%$, czyli o 3 punkty procentowe). W grupach pielęgniarek i położnych prawidłowością jest natomiast wzrost owego współczynnika w latach 2010-2012 i zdecydowana tendencja spadkowa w następnym okresie: dla pielęgniarek z 70\% w roku 2012 do $64 \%$ w roku 2016; dla położnych $-\mathrm{z} 68,5 \%$ do prawie $61 \%$.

Fakt, że liczba zatrudnionych w polskim systemie ochrony zdrowia profesjonalistów medycznych jest o ok. 35-40\% niższa od liczby osób posiadających prawo wykonywania zawodu wynika $\mathrm{z}$ tego, że w grupie osób zarejestrowanych, tzn. mających prawo wykonywania zawodu - oprócz pracujących w placówkach ochrony zdrowia - są także osoby:

- pracujące w innych zawodach;

- pracujacce za granica;

- przebywające na urlopach macierzyńskich i wychowawczych;

- przebywające na emeryturze lub rencie. Do podjęcia pracy poza systemem opieki zdrowotnej w kraju oraz do wyjazdu do pracy za granicą motywują posiadających prawo wykonywania zawodu lekarzy, pielę- 
gniarki i położne przede wszystkim trudne warunki pracy w Polsce, brak wyraźnej ścieżki kariery zawodowej (np. w przypadku lekarzy - utrudniony dostęp do specjalizacji) i - a czasami przede wszystkim - niskie wynagrodzenia oferowane w sektorze ochrony zdrowia (przede wszystkim pielęgniarkom i położnym) (Haczyński $\mathrm{i}$ in., 2018).

Emigracja z Polski lekarzy, pielęgniarek i położnych nasiliła się po wejściu Polski do Unii Europejskiej. Na terenie UE dostęp do wykonywania zawodu medycznego podlega harmonizacji w zakresie niezbędnym do swobodnego przepływu osób i usług w ramach wspólnego rynku (na podstawie zapisów Traktatu Ustanawiającego Wspólnotę Europejską). Dla profesjonalistów medycznych oznacza to pełną swobodę przemieszczania się pomiędzy krajami członkowskimi, swobodę wykonywania zawodu lub podejmowania działalności.

Trudno precyzyjnie określić liczbe polskich profesjonalistów medycznych, którzy wyjechali do pracy za granica - pewnym miernikiem potencjalnego zainteresowania emigracją jest liczba zaświadczeń o kwalifikacjach zawodowych wydawanych przez profesjonalne stowarzyszenia, tj. izby lekarskie oraz izby pielęgniarek i położnych.

Zgodnie $\mathrm{z}$ danymi zawartymi $\mathrm{w}$ raporcie Naczelnej Izby Lekarskiej w 2015 r. zaświadczenia potwierdzajace posiadanie formalnych kwalifikacji zawodowych wydano ponad 9300 lekarzom ubiegającym się o uznanie kwalifikacji w innych krajach UE. Stanowiło to 7,1\% osób wykonujących zawód lekarza (Zgliczynski i in., 2016).

Według danych Naczelnej Izby Pielęgniarek i Położnych w okresie 1.05.200431.12.2013 wydano ponad 16000 ,zaświadczeń na potrzeby uznawania kwalifikacji zawodowych" (Zabezpieczenie, 2015).

Liczba wydawanych zaświadczeń nie jest w pełni miarodajnym wskaźnikiem, gdyż często profesjonaliści medyczni (zwłaszcza pielęgniarki) podejmują prace $\mathrm{w}$ innych krajach bez pobranego w Polsce zaświadczenia. Emigracja personelu medycznego jest szczególnie niekorzystna dla przyszłości polskiego systemu opieki zdrowotnej, ponieważ emigrują najczęściej osoby młode i energiczne, mające wysokie kwalifikacje zawodowe, z dobrą znajomością języków obcych.

Fakt, że tylko część osób posiadających prawo wykonywania zawodu podej- muje zatrudnienie w placówkach systemu ochrony zdrowia w kraju nie jest zjawiskiem występującym tylko w Polsce. Odnotowuje sie je także w innych krajach europejskich. Na przykład w przypadku lekarzy zbliżony do osiąganego w Polsce wskaźnik wykorzystania zasobów w placówkach ochrony zdrowia wystąpił w latach 2012-2014 we Włoszech (ok. 60\%). Wyższe, bo ok. 70-procentowe wykorzystanie w sektorze opieki medycznej lekarzy posiadających prawo wykonywania zawodu charakteryzowało w ostatnich 10 latach systemy ochrony zdrowia Niemiec i Szwecji, a wskaźniki zawierające się $\mathrm{w}$ przedziale 75-80\% cechowały systemy opieki medycznej Hiszpanii, Norwegii i Wielkiej Brytanii (Haczyński i in., 2017).

W przypadku Polski dochodzi jednak jeszcze dodatkowa, niezwykle istotna, a niekorzystna okoliczność - otóż Polska jest krajem zajmującym odległe miejsca w zestawieniach, budowanych na podstawie wskaźników prezentujących liczbę lekarzy i pielęgniarek w przeliczeniu na 1000 mieszkańców kraju (OECD, 2017; Haczyński i in., 2018).

W zestawieniu praktykujących lekarzy przypadających na 1000 mieszkańców w europejskich krajach OECD w 2015 r. Polska zajęła - ze wskaźnikiem 2,3 lekarza - przedostatnią pozycję (gorsza sytuacja wystapiła jedynie w Turcji). Należy także zauważyć, że w latach 2000-2015 w większości krajów europejskich odnotowano - i to czasami zdecydowany - wzrost poziomu owego wskaźnika np. w Austrii - z 3,9 w 2000 r. do 5,1 lekarza na 1000 mieszkańców w roku 2015; w Norwegii - wzrost z 3,4 do 4,4; na Litwie - z 3,6 do 4,3; w Niemczech - wzrost z 3,3 do 4,1. W Polsce w tym okresie odnotowano jedynie minimalny wzrost wskaźnika lekarzy przypadających na 1000 mieszkańców - z poziomu 2,2 do 2,3 (OECD, 2017).

Również niekorzystnie przedstawia się sytuacja Polski w zestawieniu praktykujących pielęgniarek przypadających na 1000 mieszkańców - Polska zajmuje w nim jedno z ostatnich miejsc wśród europejskich krajów OECD: analizowany wskaźnik wzrósł w latach 2000-2015 z poziomu 5,0 do jedynie 5,2 (gorsza sytuacja występowała jedynie w Turcji, Grecji i na Łotwie). W większości krajów europejskich odnotowano w tym okresie zwiększenie liczby praktykujących pielęgniarek przypadających na 1000 
mieszkańców (np. w Szwajcarii - z 12,9 do 18 w roku 2015, w Danii - z 12,4 do 16,7, w Finlandii - z 10,7 do 14,7, we Francji - z 6,7 do 9,9). (OECD, 2017; Haczyński i in., 2018).

Jedynie w międzynarodowych zestawieniach położnych Polska - ze wskaźnikiem 0,93 na 1000 mieszkańców - plasuje się czołówce krajów europejskich. Wyższymi wskaźnikami legitymują się jedynie dwa kraje skandynawskie: Szwecja $(1,19)$ i Finlandia (1,03) (Skrzypczak, 2018). Należy jednak mieć na uwadze fakt, że położne odgrywają różną rolę w organizacji systemów opieki medycznej w poszczególnych krajach i mają mocno zróżnicowany zakres uprawnień i obowiązków.

\section{Starzenie się polskich profesjonalistów medycznych}

Cechą charakteryzująca grupy profesjonalistów medycznych w Polsce jest ich specyficzna struktura wiekowa, z dominującym udziałem (60-70\%) osób liczących „45 lat i więcej" oraz z rosnącym w szybkim tempie udziałem grupy wiekowej „55 lat i więcej”. Oznacza to rosnace zaawansowanie wiekowe przeciętnego specjalisty medycznego, czyli starzenie się polskich profesjonalistów medycznych.

W tabeli 2 przedstawiono strukturę według wieku lekarzy, pielęgniarek i położnych mających prawo wykonywania zawodu w latach 2012-2016.

Tabela 2. Struktura wg wieku uprawnionych do wykonywania zawodu lekarzy, pielęgniarek i położnych w latach 2012-2016 (w \%, wg stanu na dzień 31 grudnia)

\begin{tabular}{|l|c|c|c|c|c|}
\hline \multirow{2}{*}{} & \multicolumn{5}{|c|}{ Struktura wedlug wieku } \\
\cline { 2 - 6 } & poniżej 35 lat & $\mathbf{3 5 - 4 4}$ lat & $\mathbf{4 5 - 5 4}$ lat & $\mathbf{5 5 - 6 4 ~ l a t ~}$ & 65 lat i więcej \\
\hline Lekarze & & & & & \\
\hline 2012 & 17,0 & 19,3 & 23,9 & 19,4 & 20,4 \\
\hline 2013 & 17,5 & 18,2 & 23,3 & 20,1 & 20,9 \\
\hline 2015 & 17,7 & 17,2 & 23,0 & 20,7 & 21,4 \\
\hline 2016 & 17,9 & 16,3 & 22,8 & 21,1 & 21,9 \\
\hline Pielęgniarki & 18,7 & 15,7 & 22,4 & 21,2 & 22,1 \\
\hline 2012 & & & & & \\
\hline 2013 & 8,8 & 29,9 & 33,5 & 22,3 & 5,5 \\
\hline 2014 & 8,3 & 29,1 & 33,9 & 23,8 & 4,9 \\
\hline 2015 & 8,4 & 25,6 & 34,0 & 26,0 & 6,0 \\
\hline 2016 & 8,8 & 22,3 & 34,1 & 27,3 & 7,5 \\
\hline Położne & 9,1 & 19,5 & 34,1 & 27,8 & 9,5 \\
\hline 2012 & 13,5 & 28,5 & 35,8 & 18,3 & 3,9 \\
\hline 2013 & 13,6 & 25,3 & 34,3 & 21,4 & 5,4 \\
\hline 2014 & 13,5 & 22,9 & 34,8 & 22,6 & 6,2 \\
\hline 2015 & 14,4 & 19,7 & 34,3 & 23,7 & 7,9 \\
\hline 2016 & 15,4 & 17,7 & 33,3 & 24,8 & 8,8 \\
\hline
\end{tabular}

Źródło: opracowanie własne na podstawie: Biuletyn Statystyczny Ministerstwa Zdrowia z lat 2011-2017, Centrum Systemów Informacyjnych Ochrony Zdrowia, Warszawa, www.csioz.gov.pl oraz dane z zestawień pielęgniarek i położnych klasyfikowanych wg wieku www.arch.nipip.pl (dostęp 2.05.2018). 
Analiza danych zawartych w tabeli 2 pozwala stwierdzić, że w latach 2012-2016 wzrósł udział dwóch najstarszych grup wiekowych, tj. „55-64 lata” oraz „65 lat i więcej" w strukturze mających prawo wykonywania zawodu lekarzy, pielęgniarek i położnych. Systematycznie zmniejszał się natomiast udział w strukturze wiekowej grupy „35-44 lata” (z najmniejszą siła wśród lekarzy - spadek udziału o ponad 3 punkty procentowe; z bardzo dużą siłą w grupie pielęgniarek - spadek o ponad $10 \mathrm{pp}$ i położnych - spadek o ponad $11 \mathrm{pp})$. Udział najmłodszej grupy wiekowej - „poniżej 35 lat” jest względnie stabilny (z niewielką tendencją wzrostową).

Należy mieć jednak na uwadze fakt, że prezentowane zestawienie dotyczy struktury według wieku profesjonalistów medycznych posiadających prawo wykonywania zawodu, a nie praktykujących w zawodzie na terenie Polski - a to właśnie najmłodsi lekarze, pielęgniarki i położne najczęściej decydują się na emigrację i pracę $\mathrm{w}$ zawodzie poza granicami kraju lub na pozostanie w kraju, ale odejście z zawodu (Buchan i in., 2014). Należy zatem domniemywać, iż struktura wg wieku profesjonalistów medycznych zatrudnionych w sektorze ochrony zdrowia w Polsce jest jeszcze bardziej niekorzystna.

Dla grupy lekarzy charakterystycznym jest znaczaccy (ponad 20\%) i mający tendencję wzrostową udział osób w wieku powyżej 65 lat (rysunek 2). Niewiele mniejszy (liczący około 20\%) udział w strukturze wg wieku mają lekarzy z grupy wiekowej: 5564 lata. A zatem - ponad $40 \%$ lekarzy mających prawo wykonywania zawodu stanowią osoby w wieku ,55 i więcej” lat.

Udział w strukturze wiekowej lekarzy mających mniej niż 35 lat ukształtował się $\mathrm{w}$ analizowanym okresie $\mathrm{w}$ przedziale 17-18,7\% (niewielka tendencja wzrostowa), ale - jak już wspominano - można przypuszczać, że właśnie wśród najmłodszych lekarzy odsetek emigrujących jest największy.

Rysunek 2. Struktura według wieku lekarzy mających prawo wykonywania zawodu w Polsce w roku 2016 (\%)

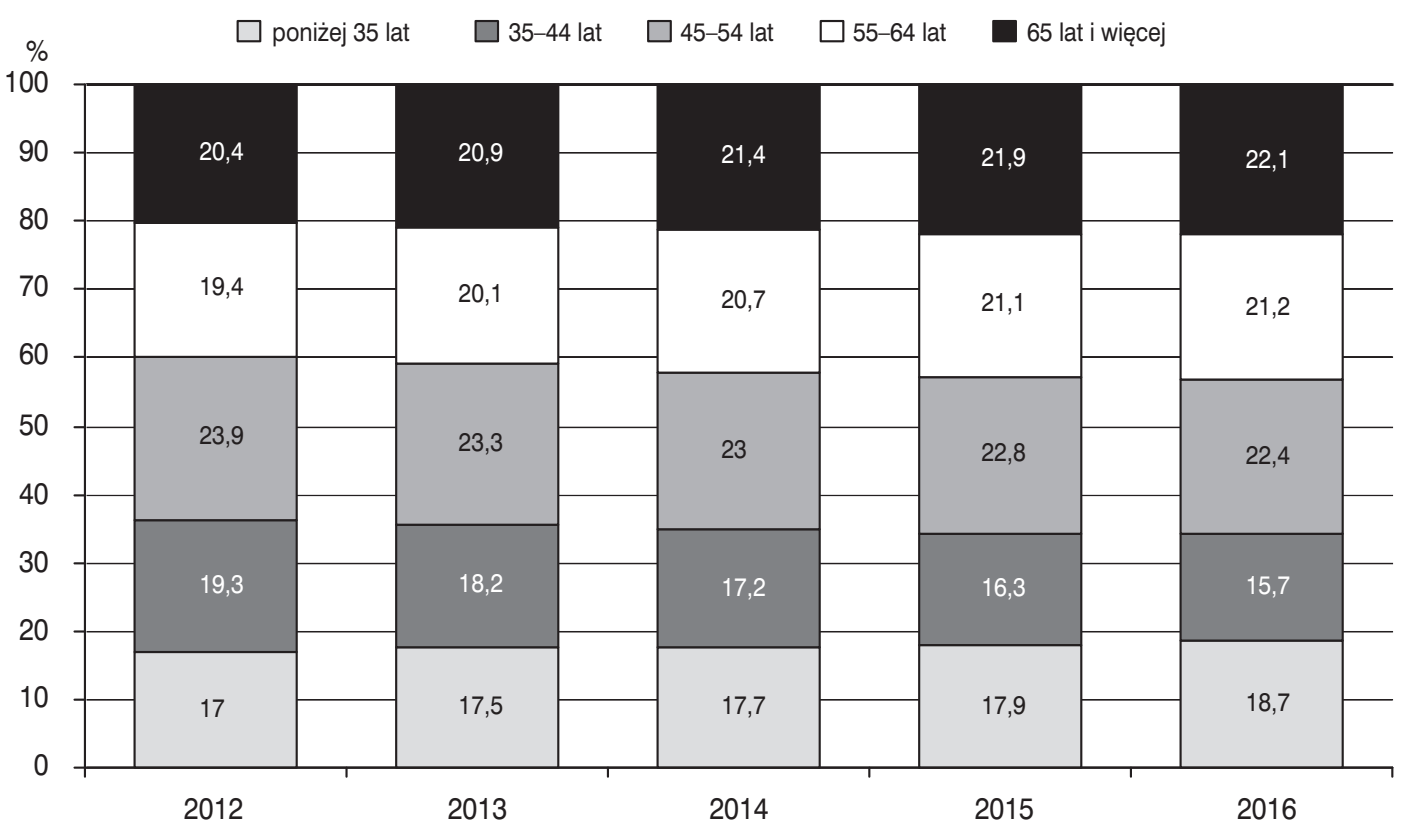

Źródło: opracowanie własne na podstawie tabeli 2.

Ośrodek Analiz, Studiów i Informacji Naczelnej Izby Lekarskiej określił dla roku 2015 średnią wieku lekarzy na
49,5 lat, a lekarza specjalisty - na 54,5 lat. W tabeli 3 przedstawiono średnią wieku dla lekarzy wybranych specjalności. 
Tabela 3. Średnia wieku lekarzy wybranych specjalności w 2015 roku

\begin{tabular}{|l|c|}
\hline \multicolumn{1}{|c|}{ Specjalnośćc } & Średnia wieku \\
\hline Alergologia & 55,6 \\
\hline Anestezjologia & 52,7 \\
\hline Chirurgia dziecięca & 56,0 \\
\hline Chirurgia klatki piersiowej & 54,6 \\
\hline Chirurgia ogólna & 55,2 \\
\hline Chirurgia onkologiczna & 52,9 \\
\hline Choroby wewnętrzne & 52,9 \\
\hline Dermatologia & 56,1 \\
\hline Geriatria & 51,7 \\
\hline Kardiochirurgia & 49,8 \\
\hline Kardiologia & 51,3 \\
\hline Okulistyka & 54,2 \\
\hline Onkologia & 47,6 \\
\hline Ortopedia & 51,9 \\
\hline Pediatria & 56,1 \\
\hline Położnictwo i ginekologia & 56,1 \\
\hline Psychiatria & 50,9 \\
\hline Reumatologia & 57,3 \\
\hline Urologia & 54,7 \\
\hline
\end{tabular}

Źródło: Zestawienie własne na podstawie: „Demografia lekarza specjalisty”, załącznik nr 1, Ośrodek Analiz, Studiów i Informacji Naczelnej Izby Lekarskiej, https://www.nil.org.pl/_data/assets/pdf_ file/0006/99744/zalacznik-1-do-demografia-2015-v-0704.pdf (dostęp: 2.05.2018).

Wśród pielęgniarek (rysunek 3) odno- wzrost udziału grupy wiekowej „,55-64 towano w latach 2012-2016 zdecydowany lata": z 22,3\% do 27,8\% (o 5,5 pp) i mniej-

Rysunek 3. Struktura według wieku pielęgniarek mających prawo wykonywania zawodu w Polsce w roku 2016 (\%)

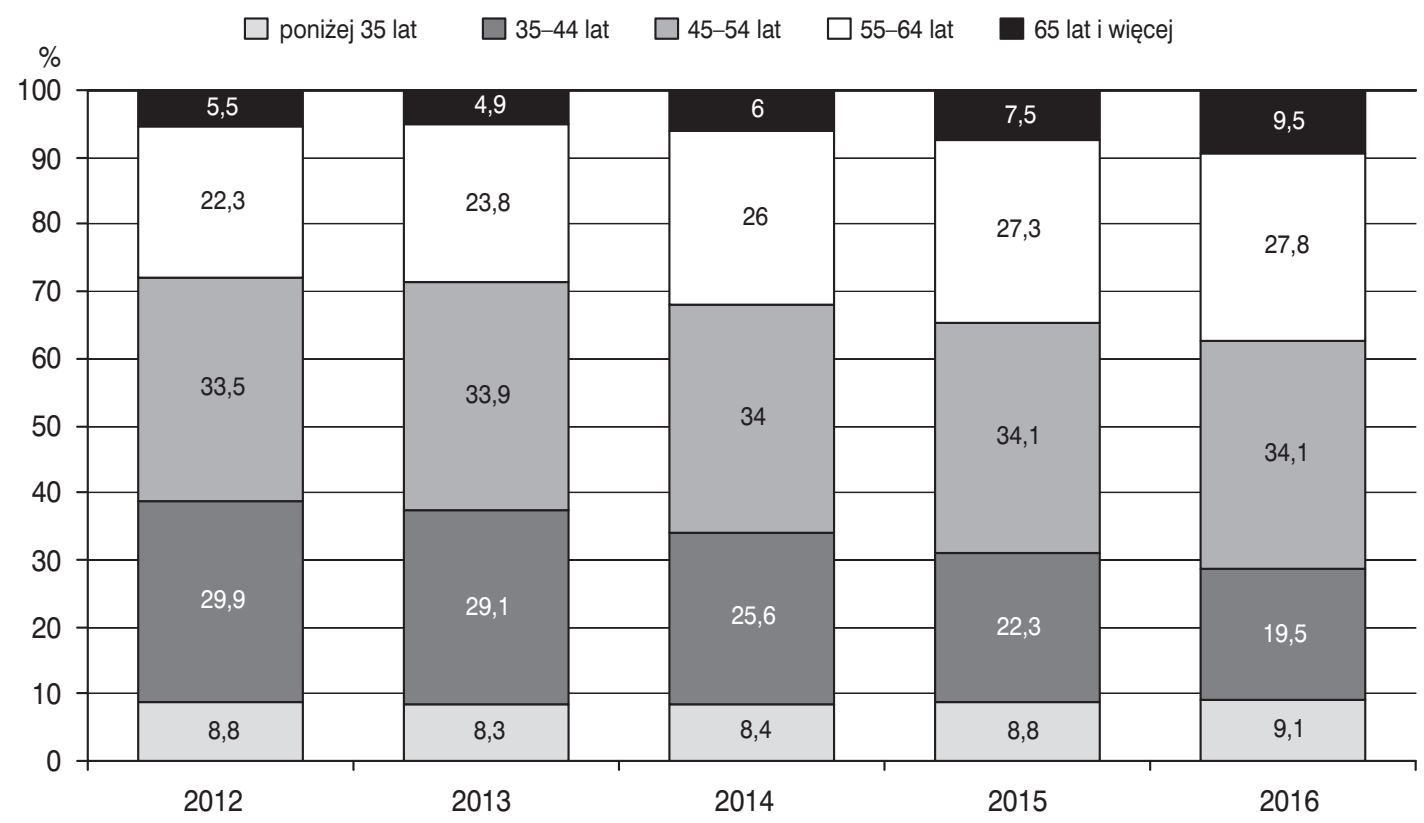

Źródło: opracowanie własne na podstawie tabeli 2. 
szy grupy wiekowej „,65 lat i więcej”: z 5,5\% do $9,5 \%$ (o 4 pp), przy jednoczesnym bardzo silnym spadku udziału grupy wiekowej ,35-44 lata": z prawie 30\% do 19,5\% (o ponad $10 \mathrm{pp}$ ).

W grupie położnych (rysunek 4) odnotowano w latach 2012-2016 zbliżone tendencje, jak te cechujące populację pol- skich pieleggniarek. Nastąpił zdecydowany wzrost udziału grupy wiekowej ,,55-64 lata" z 18,3\% do 24,8\% (o 6,5 pp) i nieco mniejszy wzrost udziału grupy wiekowej „65 lat i więcej": z ok. $4 \%$ do $9 \%$ (o ok. 5 pp), przy jednoczesnym bardzo silnym spadku udziału grupy wiekowej ,35-44 lata”: z 28,5\% do ok. 17,5\% (spadek o 11 pp).

Rysunek 4. Struktura według wieku położnych mających prawo wykonywania zawodu w Polsce w roku 2016 (\%)

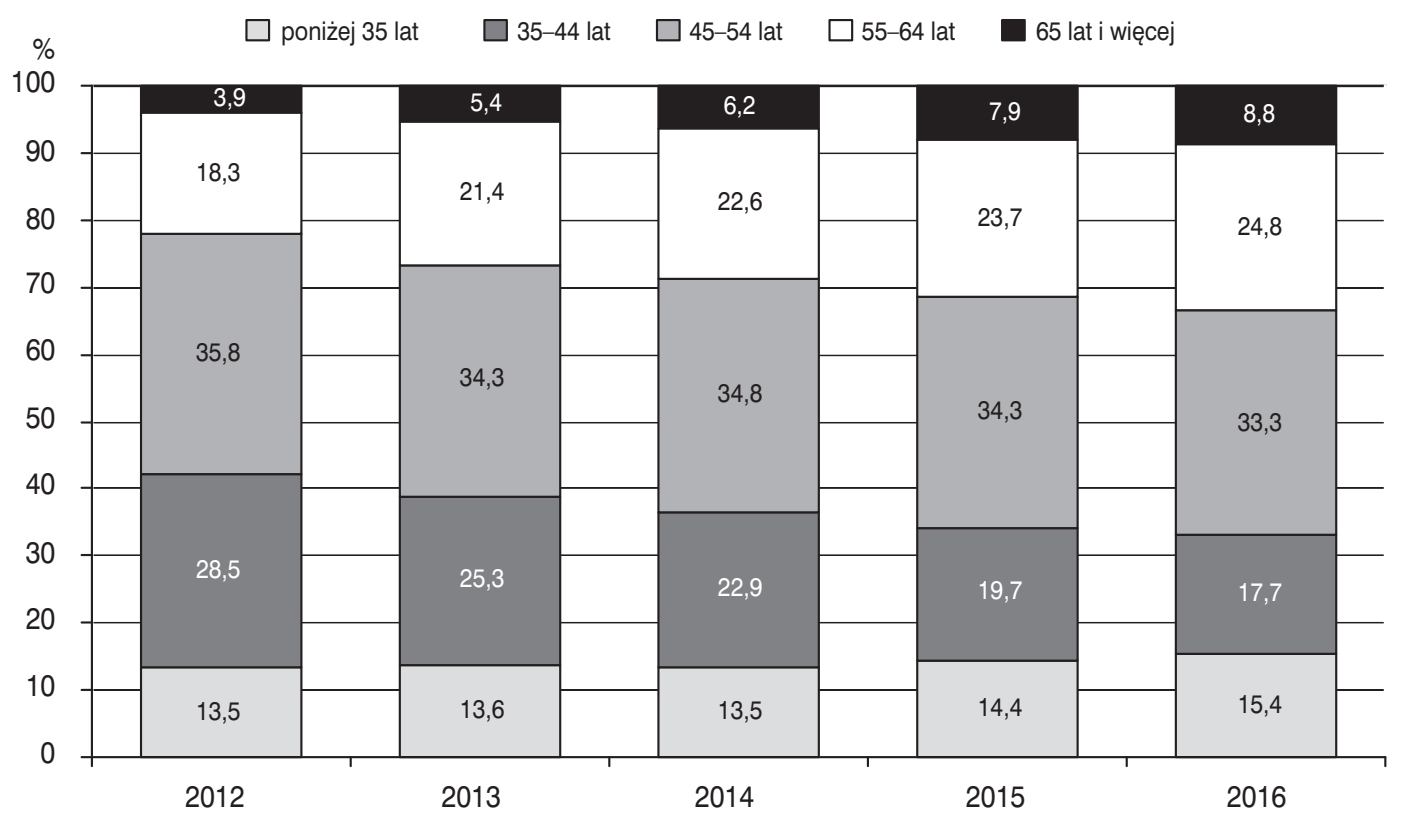

Źródło: opracowanie własne na podstawie tabeli 2.

Zaprezentowane dla populacji pielęgniarek i położnych zmiany w strukturze wiekowej znajdują wyraźne odzwierciedle- nie w zdecydowanie i systematycznie rosnącej średniej wieku tych profesjonalistów (rysunek 5).

Rysunek 5. Średnia wieku pielęgniarek i położnych w Polsce w latach 2008-2016

$\sim$ pielęgniarki $=$ położne

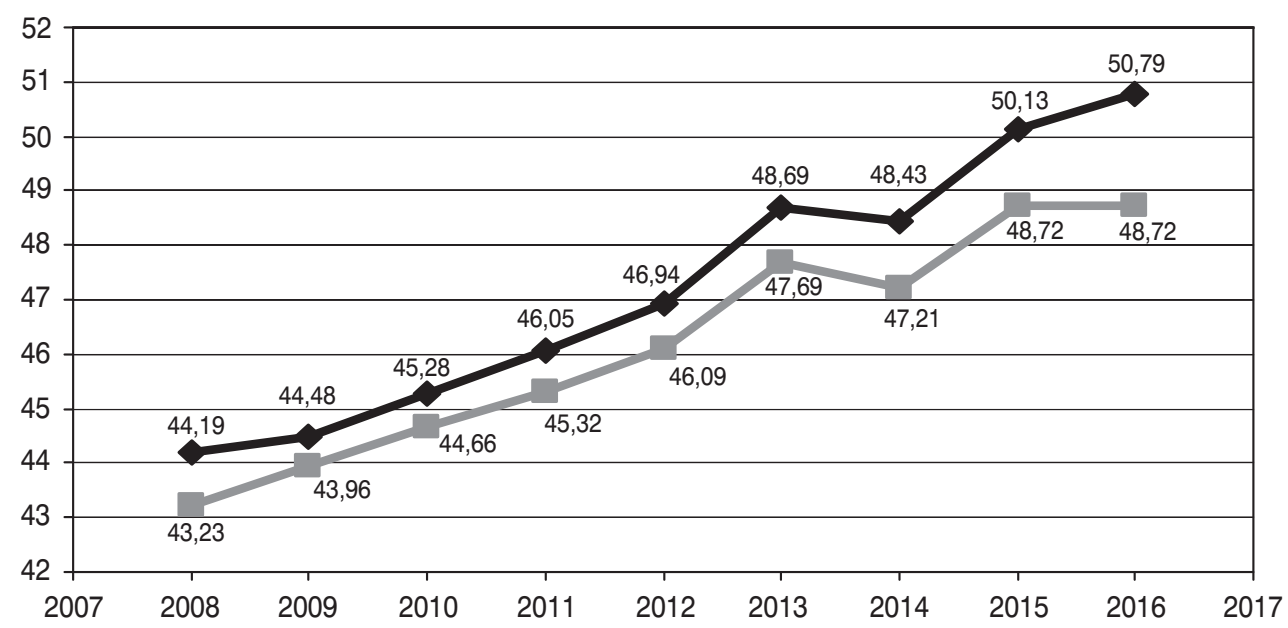

Źródło: opracowanie własne na podstawie: Zabezpieczenie społeczeństwa polskiego w świadczenia pielęgniarek i położnych, Raport Naczelnej Rady Pielęgniarek i Położnych, Warszawa, marzec 2017. 
Średnia wieku pielęgniarki w latach 2008-2016 wzrosła z nieco ponad 44 lat do prawie 51 lat, a średnia wieku położnej - wzrosła z nieco ponad 43 lat do prawie 49 lat. W obu zatem profesjach w ciagu niespełna 10 lat odnotowano wzrost średniej wieku o 5,5-6,5 lat.
Na rysunku 6 zestawiono strukturę wg wieku lekarzy, pielęgniarek i położnych mających prawo wykonywania zawodu w roku 2016 (według stanu na dzień 31 grudnia).

Rysunek 6. Struktura wg wieku uprawnionych do wykonywania zawodu lekarzy, pielęgniarek i położnych (stan na dzień 31 grudnia 2016 roku)

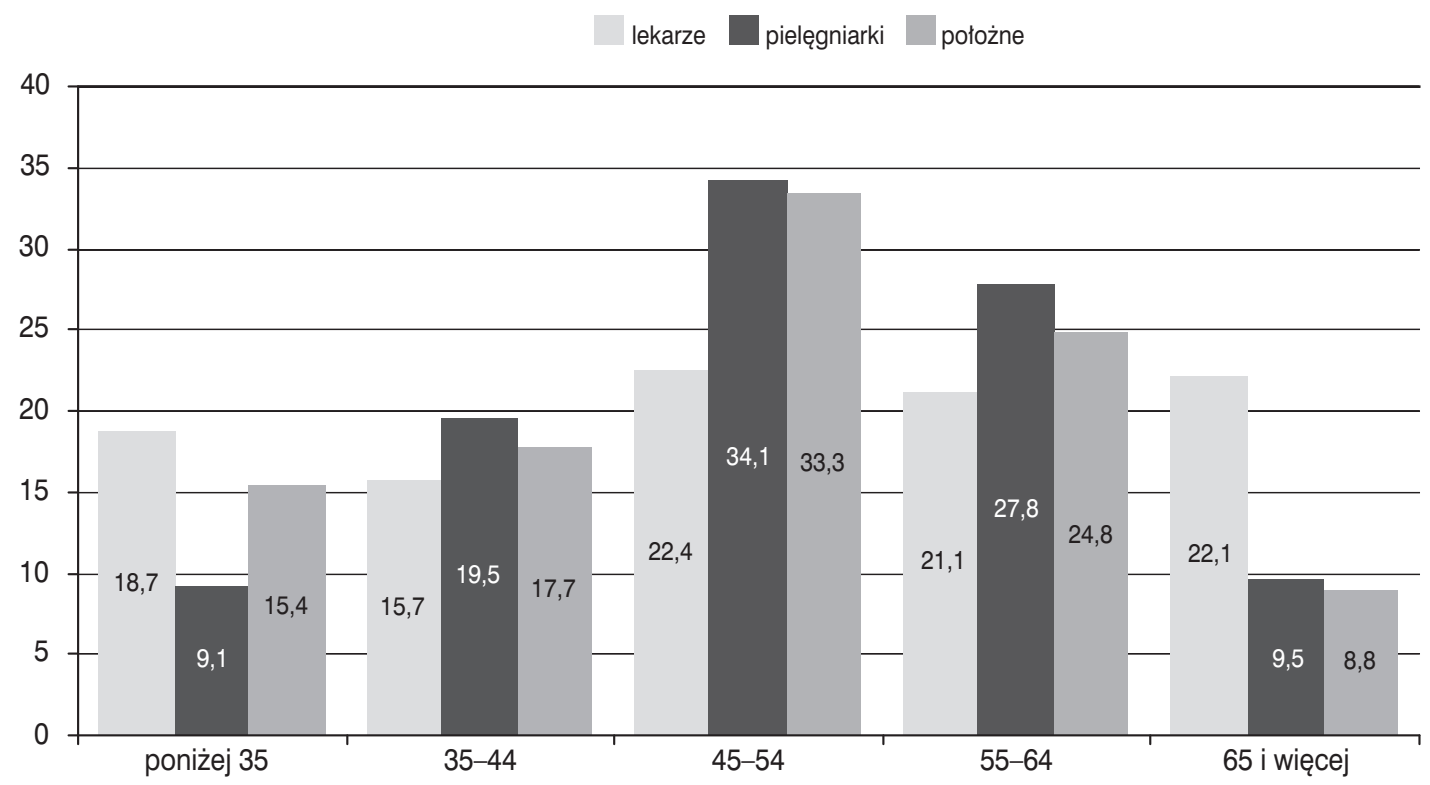

Źródło: opracowanie własne na podstawie Biuletynu Statystycznego Ministerstwa Zdrowia 2017, CSIOZ Warszawa 2017, www.csioz.gov.pl/staystyka/biuletyn-statystyczny/

Na dzień 31 grudnia 2016 roku ponad $22 \%$ lekarzy, 9,5\% pielęgniarek i prawie $9 \%$ położnych, mających prawo wykonywania zawodu stanowiły osoby w wieku „65 lat i więcej"; ponad $21 \%$ lekarzy, prawie $28 \%$ pielęgniarek i prawie $25 \%$ położnych - było w wieku ,55-64 lata”. Niespełna 19\% lekarzy, tylko 9\% pielęgniarek i ponad $15 \%$ położnych uprawnionych do wykonywania zawodu stanowiły osoby młode, mające „,poniżej 35 lat”. Jest to bardzo niepokojące zjawisko, świadczące o braku zastępowalności pokoleniowej w tych, tak bardzo ważnych dla prawidłowego funkcjonowania systemu opieki zdrowotnej, profesjach medycznych (Haczyński i in., 2017).

Porównanie wskaźnika przedstawiającego udział w populacji polskich lekarzy tych w wieku ,55 lat i więcej” - 43,3\% (rok 2016) z danymi statystyki międzynarodowej pozwala na stwierdzenie, że większy lub zbliżony udział lekarzy tej grupy wiekowej charakteryzował także inne kraje euro- pejskie (rok 2015), np.: Włochy - 53,3\%, Estonia - 46,7\%, Francja - 46,6\%, Lotwa $-46,2 \%$, Belgia $-44,4 \%$, Niemcy $-43,9 \%$ (OECD, 2017). Długi okres edukacji i kształcenia zawodowego młodej kadry spowoduje zatem w wielu krajach powstanie w najbliższym czasie luki pokoleniowej, w wyniku której osoby podejmujące pracę zawodową będą miały ograniczone możliwości nauki zawodu od starszych, doświadczonych specjalistów.

\section{Starzejący się personel medyczny w starzejącym się spoleczeństwie Polski}

Przygotowany w roku 2015 przez Komisję Europejską The 2015 Ageing Report wymienia Polskę jako jeden z krajów, w którym w nadchodzących latach wystąpi z dużym nasileniem zjawisko starzenia się społeczeństwa (The 2015 Ageing, 2016). 
Tabela 4. Liczba mieszkańców Polski i ich struktura według wieku w 2013 roku oraz prognoza na lata 2020-2060

\begin{tabular}{|c|c|c|c|c|c|c|c|c|c|c|}
\hline & 2013 & 2020 & 2025 & 2030 & 2035 & 2040 & 2045 & 2050 & 2055 & 2060 \\
\hline $\begin{array}{l}\text { Ludność ogółem } \\
(\mathrm{mln})\end{array}$ & 38,5 & 38,4 & 38,0 & 37,5 & 36,8 & 36,2 & 35,5 & 34,8 & 34,0 & 33,2 \\
\hline \multicolumn{11}{|l|}{$\begin{array}{l}\text { w tym: } \\
\text { (\% udział) }\end{array}$} \\
\hline $\begin{array}{l}\text { Dzieci } \\
\text { (0-14 lat) }\end{array}$ & 15,0 & 15,3 & 14,5 & 13,6 & 12,8 & 12,6 & 12,9 & 13,2 & 13,2 & 13,0 \\
\hline $\begin{array}{l}\text { Populacja w wieku } \\
25-54 \text { lata }\end{array}$ & 43,6 & 43,0 & 42,4 & 40,7 & 38,8 & 36,3 & 34,8 & 33,8 & 33,5 & 33,6 \\
\hline $\begin{array}{l}\text { Pracujący w wieku } \\
\text { 15-64 lat }\end{array}$ & 70,5 & 66,3 & 64,3 & 63,7 & 63,5 & 62,2 & 59,8 & 56,9 & 55,0 & 54,1 \\
\hline $\begin{array}{l}\text { Populacja osób } \\
\text { powyżej } 65 \text { roku } \\
\text { życia }\end{array}$ & 14,5 & 18,4 & 21,2 & 22,7 & 23,7 & 25,1 & 27,3 & 29,9 & 31,8 & 33,0 \\
\hline $\begin{array}{l}\text { Populacja osób } \\
\text { w wieku } 80 \text { lat } \\
\text { i więcej }\end{array}$ & 3,8 & 4,4 & 4,4 & 5,8 & 7,7 & 9,2 & 9,5 & 9,5 & 10,4 & 12,3 \\
\hline
\end{tabular}

Źródło: zestawienie na podstawie The 2015 Ageing Report, EUROPEAN ECONOMY 3|2015, Economic and Financial Affairs, Economic and budgetary projections for the 28 EU Member States (2013-2060), European Union, 2016, s. 379.

Zgodnie z prognozami Komisji Europejskiej - do 2060 r. ludność całej Polski zmniejszy się z 38,5 mln do 33,2 mln osób (czyli o ok. $5 \mathrm{mln}$ ). Szczególnie silny spadek liczebności dotyczyć będzie grupy wiekowej 25-54 lata, która w roku 2013 stanowiła 43,6\% społeczeństwa, a w roku 2060 - jej udział zmniejszy się do 33,6\% (o 10 pp).

Udział populacji w wieku „,65+” w polskim społeczeństwie będzie systematycznie rósł: z rzeczywistego poziomu $14,5 \%$ w roku 2013 do prognozowanych: $25 \%$ w roku 2040 i $33 \%$ w roku 2060.

Udział w populacji osób w wieku „80 lat i więcej" - który w 2013 roku wynosił jedynie 3,8\% ma - zgodnie z prognozą - zwiększyć się do $9,2 \%$ w roku 2040 i do $12,3 \%$ w roku 2060.

Jak wskazują wyniki badań, wraz z wiekiem wzrasta częstość występowania chorób i dolegliwości przewlekłych (Stan zdrowia, 2016). O ile nieco ponad $25 \%$ dzieci do 15. roku życia chorowało na przynajmniej jedną chorobę lub dolegliwość przewlekłą, o tyle dla populacji ludzi dorosłych wskaźnik ten wyniósł już prawie $60 \%$.

Częstość występowania schorzeń przewlekłych wzrasta gwałtownie po ukończe- niu 50. roku życia. Ponad $80 \%$ osób będących w wieku „50 lat i więcej” deklarowało występowanie u siebie przynajmniej jednej choroby lub dolegliwości przewlekłej, podczas gdy w młodszej grupie (40-49 lat) - taką deklarację złożyła jedynie mniej więcej co druga osoba. Należy pamiętać, że występowanie choroby przewlekłej wymaga systematycznej opieki medycznej, kontaktów zarówno z lekarzem podstawowej opieki zdrowotnej, jak i specjalistą, regularnego brania leków; wśród osób starszych jest również wyższy odsetek osób niepełnosprawnych.

W tabeli 5 zestawiono średnią liczbę wizyt u lekarzy ogólnych i u lekarzy specjalistów dla różnych grup wiekowych w populacji osób dorosłych (badania przeprowadzono w 2014 r.).

Wyraźnie widać, że liczba wizyt u lekarza (na 100 osób) wzrasta wraz z wiekiem i w przypadku osób „powyżej 70 lat” jest: w przypadku lekarza podstawowej opieki zdrowotnej ponad trzykrotnie wyższa, a w przypadku lekarza specjalisty - około dwukrotnie wyższa niż liczba wizyt osób 20- lub 30-letnich. 
Tabela 5. Średnia liczba wizyt osób dorosłych u lekarza POZ i specjalisty w ciągu 4 tygodni

\begin{tabular}{|l|c|c|c|c|}
\hline \multirow{3}{*}{ Wiek } & \multicolumn{4}{|c|}{ Średnia liczba wizyt u lekarza } \\
\cline { 2 - 5 } & \multicolumn{2}{|c|}{$\begin{array}{c}\text { ogólnego (lekarza POZ) } \\
\text { lub rodzinnego }\end{array}$} & \multicolumn{2}{c|}{ specjalisty } \\
\cline { 2 - 5 } & $\begin{array}{c}\text { na 100 osób } \\
\text { korzystających }\end{array}$ & na 100 osób & $\begin{array}{c}\text { na 100 osób } \\
\text { korzystających }\end{array}$ & na 100 osób \\
\hline $20-29$ & 65 & 26 & 82 & 23 \\
\hline $30-39$ & 68 & 30 & 81 & 27 \\
\hline $40-49$ & 78 & 39 & 84 & 29 \\
\hline $50-59$ & 86 & 54 & 90 & 38 \\
\hline $60-69$ & 98 & 75 & 91 & 49 \\
\hline $70-79$ & 113 & 95 & 103 & 63 \\
\hline 80 lat i więcej & 112 & 96 & 90 & 49 \\
\hline
\end{tabular}

Źródło: zestawienie własne na podstawie Stan zdrowia ludności Polski w 2014 roku (2016). Warszawa: GUS, s. 130, tabela 20, http://stat.gov.pl/obszary-tematyczne/zdrowie/zdrowie/stan-zdrowia-Iudnoscipolski-w-2014-r-,6,6.html

W tabeli 6 przedstawiono strukturę polskiej populacji oraz strukturę porad ambu-

latoryjnych według wieku pacjentów w 2016 roku.

Tabela 6. Struktura populacji oraz struktura porad ambulatoryjnych według wieku pacjentów w Polsce w 2016 roku

\begin{tabular}{|l|c|c|c|c|}
\hline & \multirow{2}{*}{$\begin{array}{c}\text { Struktura ludności } \\
\text { wg wieku } \\
\text { (stan na 30.06.2016) }\end{array}$} & POZ & specjalistyczne & stomatologiczne \\
\cline { 3 - 5 } & 17,9 & 21,7 & 12,9 & 29,0 \\
\hline 0-17 lat & 66,0 & 46,8 & 59,6 & 56,6 \\
\hline 18-64 lata & $\mathbf{1 6 , 1}$ & $\mathbf{3 1 , 5}$ & $\mathbf{2 7 , 5}$ & $\mathbf{1 4 , 4}$ \\
\hline 65+ lat & 100,0 & 100,0 & 100,0 & 100,0 \\
\hline Ogółem & &
\end{tabular}

Źródło: Zdrowie i ochrona zdrowia w 2016 roku (2017). Warszawa: GUS, tab. 2c, s. 124.

Porównanie struktury wiekowej polskiego społeczeństwa ze strukturą ilości porad ambulatoryjnych udzielonych pacjentom pozwala stwierdzić, że osoby w wieku 65+, stanowiące w 2016 r. ok. $16 \%$ polskiego społeczeństwa otrzymały: $31,5 \%$ porad lekarzy podstawowej opieki zdrowotnej i 27,5\% wszystkich porad lekarzy specjalistów.

Również opieka długoterminowa, której celem jest zapewnienie pacjentowi całodobowych świadczeń pielęgnacyjnych, opiekuńczych i rehabilitacyjnych oraz kontynuacji leczenia farmakologicznego w dłuższym czasie odgrywa coraz większą rolę wraz z postępującym procesem starzenia się społeczeństwa. Analiza struktury wieku osób przebywających w takich placówkach w 2016 r. wykazała, że ponad 75\% pacjentów stanowiły osoby w wieku „65 lat i więcej" (z czego ponad połowę stanowiły osoby w tzw. późnej starości, tj. liczące „80 lat i więcej”). Pacjenci w wieku 41-64 lata stanowili blisko $1 / 5$ podopiecznych, natomiast osoby do 40. roku życia niespełna 5\% (Zdrowie, 2017).

Także analiza korzystania z usług diagnostyki laboratoryjnej wskazuje na wyraźnie zróżnicowanie częstotliwości ze względu na wiek. Wśród osób w wieku poniżej 25 lat 
jedynie $1 / 4$ populacji wykonywała w roku 2016 badania laboratoryjne. W starszych grupach wiekowych odsetek korzystających z badań diagnostyki laboratoryjnej rósł natomiast systematycznie wraz $\mathrm{z}$ wiekiem respondentów - wśród osób najstarszych, w wieku powyżej 79 lat wyniósł już prawie 80\% (Zdrowie, 2017).

Należy stwierdzić, iż system opieki zdrowotnej nad osobami starszymi w Polsce nie spełnia standardów podejścia geriatrycznego, nie jest dostosowany do potrzeb tej części populacji, ponieważ oferuje zainteresowanym świadczenia zdezintegrowane, rozproszone i niespójne. $\mathrm{Z}$ reguły długotrwała opieka nad poważnie chorymi osobami starszymi spoczywa w Polsce głównie na barkach rodziny, która w niedostatecznym stopniu wspomagana jest usługami medycznymi i pozamedycznymi systemu opieki społecznej państwa. Eksperci zwracają także uwagę na niedostateczne przygotowanie lekarzy podstawowej opieki zdrowotnej do opieki geriatrycznej oraz brak zharmonizowania opieki wysokospecjalistycznej, co może stać się przyczyną nieskutecznego leczenia lub pogorszenia się stanu zdrowia chorych w starszym wieku. Dyskryminacja w zakresie procedur diagnostycznych i leczniczych ze wzgledu na wiek, brak pełnej geriatrycznej analizy przeciwwskazań podczas kwalifikowania chorych do wysokospecjalistycznych procedur bywa przyczyną nieskuteczności leczenia lub wystąpienia działań niepożądanych u dużej części chorych w starszym wieku. (Haczyński, 2018).

Ocenia się, że w Polsce występują niedobory profesjonalnych kadr opieki geriatrycznej i istnieje potrzeba stworzenia kompleksowego systemu opieki geriatrycznej. O niezadowalającym poziomie specjalistycznej opieki zdrowotnej nad osobami starszymi świadczy chociażby niewielka liczba lekarzy geriatrów - w roku 2015 pracowało 328 lekarzy mających specjalizację w tym zakresie i 160 lekarzy odbywało specjalizację z geriatrii; średnia wieku lekarza geriatry wynosiła 51,7 lat (Demografia, 2015). Niezadowalajaca jest także liczba pielegniarek ze specjalizacją $\mathrm{w}$ dziedzinie pielęgniarstwa geriatrycznego oraz brakuje placówek geriatrycznych czy szpitalnych oddziałów geriatrycznych (Narodowy Fundusz Zdrowia nisko wycenia opiekę geriatryczną).

Opieka nad osobami w wieku starszym powinna być sprawowana przez wielody- scyplinarny zespół złożony $\mathrm{z}$ personelu medycznego, niemedycznego oraz wolontariuszy. Dopiero tak realizowana kompleksowa opieka zapewniłaby holistyczne spojrzenie na potrzeby osoby starszej i umożliwiła zindywidualizowanie w zakresie świadczonych usług medycznych (Karkowski, 2015).

Należy podkreślić również, że koszty opieki medycznej rosną wyraźnie wraz z wiekiem. Struktura społeczeństwa wg wieku ma istotne znaczenie dla częstości korzystania ze świadczeń, dla rodzaju otrzymywanych świadczeń i w konsekwencji - dla poziomu potrzeb zdrowotnych, wymagających sfinansowania ze środków publicznych.

Narodowy Fundusz Zdrowia szacuje poziom wydatków ponoszonych na świadczenia zdrowotne udzielane osobom w różnym wieku. W roku 2014 przeciętne roczne wydatki NFZ na 1 osobę wyniosły 1378 zł. Ale o ile wydatki na 1 osobe $\mathrm{z}$ przedziału wiekowego: 2-40 lat nie przekraczały poziomu $750 \mathrm{zl}$, o tyle dalej - wraz z wiekiem - poziom wydatków rósł w coraz szybszym tempie. Nakłady ponoszone przez NFZ na opiekę zdrowotną: przekroczyły kwotę 1000 zł w przypadku osoby 47-letniej, przekroczyły $1500 \mathrm{zl}$ dla osoby ok. 55-letniej, przekroczyły $2000 \mathrm{zł}$ w przypadku osoby 60-letniej, dla osoby 65-letniej - osiągnęły poziom 2500 zł, dla osoby 68-letniej - przekroczyły 3000 zl, a dla 73-letniej - osiagnęły już poziom 3500 zł (Prognoza, 2015).

\section{Podsumowanie}

Polska - tak, jak i inne kraje europejskie - odnotowuje zjawisko systematycznego starzenia się społeczeństwa. Wydłużeniu życia towarzyszy większa ilość chorób przewlekłych, pojawiających się wraz ze starzeniem się $\mathrm{i}$ - tym samym - generujących zwiększone zapotrzebowanie na usługi medyczne. Wraz ze wzrostem średniej długości życia, postępem medycyny i oczekiwanego zwiększenia dostępności do świadczeń medycznych obserwujemy rosnącą liczbę chorób przewlekłych i częściej występującą niepełnosprawność, których koszty leczenia gwałtownie rosną - zarówno z powodu kosztów leków czy procedur medycznych, jak i z powodu zwiększającej się liczby wizyt i konsultacji medycznych oraz konieczności zapewnienia osobom starszym wysokospecjalistycznej opieki pielęgniarskiej. $\mathrm{Na}$ to 
zjawisko nakłada się równoczesne starzenie się personelu medycznego. Niekorzystne zmiany w strukturze wiekowej lekarzy, pielęgniarek i położnych, przy równoczesnej dużej skali emigracji (zwłaszcza ludzi młodych) budzą niepokój ekspertów, mówiących jednoznacznie o nadchodzącym braku tzw. zastępowalności pokoleniowej w zawodach medycznych.

Konieczne jest zatem podjęcie wielokierunkowych działań mających powstrzymać te niekorzystne zjawiska, charakteryzujące zasoby ludzkie w polskim systemie opieki zdrowotnej. Mówiąc o braku personelu medycznego, trudnej dostępności usług zdrowotnych i konieczności oczekiwania w długich kolejkach, podkreśla się zazwyczaj, iż przyczyną tych zjawisk jest niedostateczna ilość środków publicznych kierowanych do sektora opieki zdrowotnej. Nie ulega wątpliwości, że tak jest - Polska od lat zajmuje jedno $\mathrm{z}$ ostatnich miejsc $\mathrm{w}$ rankingu europejskich krajów OECD pod względem wydatków na ochronę zdrowia per capita oraz relacji wydatków na ochronę zdrowia do PKB (OECD, 2017). Ale poza zwiększeniem nakładów na ochronę zdrowia niezbędne jest również dokonanie zmian instytucjonalnych, dzięki którym znaczniejszy odsetek lekarzy, pielęgniarek i położnych podejmie po studiach pracę w kraju, a nie będzie emigrować, bądź decydować się na zatrudnienie poza sektorem opieki medycznej w poszukiwaniu korzystniejszych warunków pracy i godniejszego życia.

\section{Bibliografia}

Biuletyn Statystyczny Ministerstwa Zdrowia $z$ lat 2011-2017, Centrum Systemów Informacyjnych Ochrony Zdrowia, Warszawa, www.csioz.gov.pl

Buchan, J., Wismar, M., Glinos, I.A. i Bremner, J. (red.) (2014). Health professional mobility in a changing Europe. New dynamics, mobile individuals and diverse responses. Vol. II. The European Observatory on Health Systems and Policies, Observatory Studies Series, 32. WHO, Copenhagen

Demografia lekarza specjalisty (2015). Załącznik nr 1, Ośrodek Analiz, Studiów i Informacji Naczelnej Izby Lekarskiej, https://www.nil.org.pl/_data/ assets/pdf_file/0006/99744/zalacznik-1-do-demografia-2015-v-0704.pdf (dostęp: 2.05.2018).

Haczyński, J. (2018). Skutki starzenia się polskiego społeczeństwa. W: K. Ryć, J. Haczyński i Z. Skrzypczak (red.), Ochrona zdrowia i gospodarka. Pacjenci, swiadczeniodawcy, turystyka medyczna. Warszawa: Wydawnictwo WZ UW.
Haczyński, J., Skrzypczak Z. i Winter, M. (2017). Nurses in Poland - immediate action needed. Engineering Management in Production and Services, 9(2), 97-104.

Haczyński, J., Ryć, K., Skrzypczak, Z. i Suchecka, J. (2017). Zasoby lekarzy w systemie ochrony zdrowia - Polska na tle wybranych krajów europejskich. Problemy Zarzadzania, 3(2).

Haczyński, J., Ryć, K. i Skrzypczak Z. (2018). Nurses and Doctor in the Polish Healthare System. Journal of Management and Financial Science, XI(32): 115-126.

Karkowski, T. (2015). Dostosowywanie zasobów kadry medycznej do potrzeb starzejącego się społeczeństwa. Zdrowie Publiczne i Zarzadzanie, 13(1): 82-94.

OECD (2017). Health at a Glance 2017, OECD Indicators. Paris: OECD Publishing. http://dx.doi. org/10.1787/health_glance-2017-en

Prognoza kosztów świadczeń opieki zdrowotnej finansowanych przez Narodowy Fundusz Zdrowia w kontekście zmian demograficznych $w$ Polsce (2015). NFZ Departament Analiz i Strategii. Warszawa, listopad.

Skrzypczak, Z. (2018). Położne w Polsce. W: K. Ryć, J. Haczyński i Z. Skrzypczak (red.), Ochrona zdrowia i gospodarka. Pacjenci, świadczeniodawcy, turystyka medyczna. Warszawa: Wydawnictwo WZ UW.

Stan zdrowia ludności Polski w 2014 roku (2016). Warszawa: GUS, http://stat.gov.pl/obszary-tematyczne/zdrowie/zdrowie/stan-zdrowia-ludnosci-polski-w-2014-r-,6,6.html

Suchecka, J. i Jewczak, M. (2018). Starzejąca się Europa: nowe wyzwania dla „Silver Economy”. W: K. Ryć, J. Haczyński i Z. Skrzypczak (red.), Ochrona zdrowia i gospodarka. Pacjenci, świadczeniodawcy, turystyka medyczna. Warszawa: Wydawnictwo WZ UW.

The 2015 Ageing Report, EUROPEAN ECONOMY 3|2015, Economic and Financial Affairs, Economic and budgetary projections for the $28 \mathrm{EU}$ Member States (2013-2060), European Union, 2016.

Zybała, A. (red.) (2009). Wyzwania w systemie ochrony zdrowia - zasoby ludzkie i zasoby organizacyjne w centralnych instytucjach, raport na zlecenie Światowej Organizacji Zdrowia. Warszawa: KSAP.

Zabezpieczenie spoteczeństwa polskiego $w$ świadczenia pielegniarek i potożnych. Raport Naczelnej Rady Pieleggniarek i Potożnych (2017). Warszawa.

Zdrowie i ochrona zdrowia w 2016 roku (2017). Warszawa: GUS.

Zgliczynski, W.S., Cianciara, D., Śliż, D., Rostkowska, O. i Pinkas J. (2016), Physicians and dentists - staffing and training system in Poland. Postępy Nauk Medycznych, XXIX(5), 270-278. 